IRA-International Journal of Applied Sciences ISSN 2455-4499; Vol.05, Issue 03 (2016)

Institute of Research Advances

Pg. no. 115-121

http://research-advances.org/index.php/IRAJAS

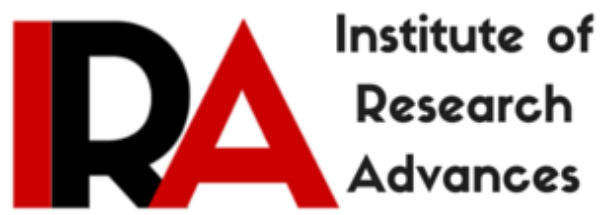

\title{
Physico-Chemcial Parameters of Puducherry Soil and the Associated Mycoflora
}

\author{
N. Arun ${ }^{1}$ \\ Research Scholar \\ Kanchi Mamunivar Centre for Postgraduate Studies (KMCPGS), \\ Lawspet, Puducherry, India. \\ B. K. Nayak ${ }^{2}$ \\ Research Supervisor \\ Kanchi Mamunivar Centre for Postgraduate Studies (KMCPGS), \\ Lawspet, Puducherry, India.
}

Type of Review: Peer Reviewed.

DOI: http://dx.doi.org/10.21013/jas.v5.n3.p2

\section{How to cite this paper:}

Arun, N., \& Nayak, B. (2016). Physico-Chemcial Parameters of Puducherry Soil and the Associated Mycoflora. IRA-International Journal of Applied Sciences (ISSN 2455-4499), 5(3), 115-121. doi:http://dx.doi.org/10.21013/jas.v5.n3.p2

(C) Institute of Research Advances

\section{(c) $)$ EY-NC}

This work is licensed under a Creative Commons Attribution-Non Commercial 4.0 International License subject to proper citation to the publication source of the work.

Disclaimer: The scholarly papers as reviewed and published by the Institute of Research Advances (IRA) are the views and opinions of their respective authors and are not the views or opinions of the IRA. The IRA disclaims of any harm or loss caused due to the published content to any party. 


\begin{abstract}
The rhizosphere region is rich with the plenty of microorganisms. It may be either pathogenic or nonpathogenic to the plants and animals. Fungi were the ubiquitous organisms present in all types of habitats (Ainsworth et al., 1995).They play a vital role in conversion of waste and degradation (Diana 1994).. There were the previous researchers so far explained more than million fungal species on earth (Barnett et al., 1972). The physcio-chemical parameter was also analyzed. The soil samples were serially diluted and inocualted on the SDA plates. The different species belongs to various groups of fungi such as Ascomycotina, Zygomycotina and Deuteromycotina were identified with the help of relevant literatures. A total of -- taxa belonging to -- genera were isolated, these include one species of Acomycetes, one species of Coelomycetes five species of Zygomycetes and remaining species were Deuteromycetes. Penicillium and species of Aspergillus were also recorded from samples. Basidiomycetes were also identified. The macro nutrients such as $N, P$ and $K$ content were not rich in the samples. There is no proper record so far regarding the fungal in these soil areas along with the soil nutrients. The present study is mainly focused on the mycoflora present in the rhizosphere regions of three different soil of puducherry region based on the macro and micronutrients present in the soil.
\end{abstract}

SUMMARY : Studies on the prevalence of soil mycoflora in three rural villages of Ariankuppam, Nonankuppam and Veerampattinam coastal village of Pondicherry were carried out by serial dilution method on June 2014. Composition and concentration of fungal spores considerably varied from these villages. Ariankuppam harbored maximum number of species its very high when compared to two other areas. It has predominant fungus in soil due to agriculture land other two areas are saline and river-bed soils In qualitative analysis, out of the total species recorded, Aspergillus was found with the highest frequency and had eight members i.e A. candidus, A.fumigatus, A. niger, A. flavus, A. flavipes, A. nidulans, A. ochraceous, A. terreus and A. versicolor. Penicillin is the second most CFUs followed by Aspergillus.

\title{
Introduction:
}

Fungi play very important role in various biogeochemical cycles (George 1989, Migahed 2003) and are responsible for the cycling of organic compounds. Soil microorganisms mainly influence the soil ecosystems by contributing to plant nutrition (Filion et al., 1999, Meyer, G. H., Prince, H. E. and Raymer,W. J. 1983) plant health (Ellis et al., 1985)and soil structure and soil fertility (Molin et al., 1997).

\section{METHODOLOGY}

\section{Study site and location}

\section{Study sites}

Pondicherry region is situated on the Coromandel Coast between $11^{0} 46^{\prime}$ and $12^{0} 30^{\prime} \mathrm{N}$ latitudes and $79^{\circ} 36^{\prime}$ and $79^{\circ} 53^{\prime}$ E longitudes. The region is bounded on the north, south and west by Marakkanam, Cuddalore and by Villupuram districts of Tamilnadu, and on the east by Bay of Bengal. It covers an area of 29377 ha, according to village revenue records and consists of 179 villages. The present study was carried out in three different localities of rural villages; Ariyankuppam(S1),Nonankuppam(S2) and Veerampattinam(S3) coastal areas on May 2014. The villages are adjacent and previously agriculture was in practice. Recently the agriculture was overthrown and buildings were raised. 


\section{Methods for collection of soil samples}

The soil samples were collected from three different localities of rural villages; Ariyankuppam(S1),Nonankuppam(S2) and Veerampattinam(S3) coastal areas on May 2014. The samples were collected 3 inches below the soil surface using the sterile spatula and carefully collected in the containers. The soil samples were collected randomly from the each place within the radius of $1 \mathrm{~km}$. The sealed containers were brought to the Microbiology Laboratory, Botany Department, KMCPGS, Puducherry for further investigation.

\section{Determination of physicochemical properties of soil samples}

The $\mathrm{pH}$ values, electrical conductivity, soil moisture, organic carbon, nitrogen, phosphorous, potassium, iron, manganese, copper and zinc were analyzed (Table 1).

\section{Data collection and analysis:}

Soil physic-chemical properties The physico-chemical properties of experimental soil: texture, $\mathrm{pH}$, organic carbon content, total nitrogen content, available phosphorus content and available potassium content, were estimated by combined glass electrode $\mathrm{pH}$ meter method, Walkley and Black's rapid titration method, modified macro Kjeldahl method, Olsen's method and flame photometer method, respectively (Jackson, 1973).

Table 1:

\begin{tabular}{|c|c|c|c|c|c|c|c|c|c|c|c|}
\hline \multirow[t]{2}{*}{ Sample } & \multirow[t]{2}{*}{ pH } & \multirow[t]{2}{*}{ EC } & \multirow[t]{2}{*}{ Lime } & \multirow{2}{*}{$\begin{array}{l}\text { Soil } \\
\text { texture }\end{array}$} & \multicolumn{3}{|c|}{ Macronutrient } & \multicolumn{4}{|c|}{ Micronutrient } \\
\hline & & & & & $\mathbf{N}$ & $\mathbf{P}$ & $\mathbf{K}$ & $\mathbf{C u}$ & Zn & Mn & $\mathbf{F e}$ \\
\hline S1 & 8.1 & 1.3 & $\mathrm{~N}$ & $\mathrm{~S}$ & $71.83 \mathrm{~L}$ & $\begin{array}{l}0.16 \\
\text { VL }\end{array}$ & $\begin{array}{l}134.4 \\
\mathrm{~L}\end{array}$ & $\begin{array}{ll}1.1 & 0 \\
\mathrm{~L} & \end{array}$ & $\begin{array}{l}1.9 \\
M\end{array}$ & $3.2 \mathrm{M}$ & $\begin{array}{l}23.0 \\
M\end{array}$ \\
\hline S2 & 7.4 & 0.17 & $\mathrm{~N}$ & $\mathrm{~S}$ & $64.90 \mathrm{~L}$ & $\begin{array}{l}19.57 \\
\mathrm{~L}\end{array}$ & $8.97 \mathrm{~L}$ & $\begin{array}{ll}1.2 & 0 \\
\mathrm{~L} & \\
\end{array}$ & $1.3 \mathrm{~L}$ & $\begin{array}{l}121 \\
\mathrm{VH} \\
\end{array}$ & $\begin{array}{l}21.3 \\
\mathrm{M} \\
\end{array}$ \\
\hline S3 & 7.8 & 1.10 & $\mathrm{~N}$ & $S$ & $\begin{array}{l}120.65 \\
\mathrm{~L}\end{array}$ & $\begin{array}{l}16.87 \\
\mathrm{~L}\end{array}$ & $\begin{array}{l}33.45 \\
\mathrm{~L}\end{array}$ & $\begin{array}{l}0.96 \\
\mathrm{~L}\end{array}$ & $\begin{array}{l}1.6 \\
M\end{array}$ & $3.6 \mathrm{M}$ & $\begin{array}{l}24.5 \\
M\end{array}$ \\
\hline
\end{tabular}

S 1 - Ariyankuppam, S 2 - Nonankuppam and S 3 - Veerampattinam

\section{Preparation of samples}

Dispensed one gram of organic sample in $10 \mathrm{ml}$ of distilled water, mixed well by Vortexing and transferred one $\mathrm{ml}$ of suspension to another test tube to make $10^{-5}$ dilution. Dilution procedure was continued up to $10^{-6}$.

\section{Spread plate methods}

Nutrient agar plates were prepared and $0.1 \mathrm{ml}$ of suspension was pipetted from each dilution on the agar surface. The L rod was dipped in 95\% alcohol which was taken in the beaker. The glass rod was removed from the beaker and the bent position was sterilised in the Bunsen burner flame. The rod was cooled for 10-15 sec. and softly touched on the agar and spread the suspension on the agar surface. The procedure was repeatedly carried out to prepare up to $10^{-6}$ and then the plates were incubated in an inverted position at $25^{\circ} \mathrm{c}$ for 24 to $48 \mathrm{hrs}$.

\section{Enumeration of colonies}

The method, Most Probable Number (MPN), was used for the enumeration of cultured colonies. The different colonies in the plate were counted manually. 


\section{Identification of organisms}

After the growth of microbial colonies in the spread plates the various colonies were differentiated by colony morphology. Then the colonies are streaked onto the different agar slants by taking a loop full of culture. From those slants a single colony was inoculated into the sterile broths and incubated for 4 to 6 hrs. These were used for further experiment.

\section{Isolation of soil mycoflora}

The soil micro fungi were enumerated by two methods, namely, Soil dilution, (Waksman, 1927), and Soil plate method (Warcup, 1950) on different media such as potato dextrose agar and Sabourard Dextrose Agar at $\mathrm{pH}$ 6.5. All the Petri dishes were incubated at room temperature $27 \pm 3^{\circ} \mathrm{C}$ for a period of $4-7$ days and then examined. The first set of observations were made at the end of two days to make sure that the fast growing flocculent types such as Rhizopus, Mucor and Trichoderma, etc., has grown excessively to interfere with observations of other species. Second observation was made when these had come to an advanced stage to enable identification. Finally, the slow growing organisms has to be subcultured in different media for the purpose of further growth to save them from being overrun by the more aggressive types. The number of colonies per plate in $1 \mathrm{~g}$ of soil was calculated.

\section{Identification}

Identification of the organisms was made by microscopic analysis using taxonomic guides, standard procedures and relevant literature (Kenneth et al., 1976; Kenneth et al., 1985; and Ellis, 1971). While presenting the data two terms, viz; periodicity of occurrence and 'percent contribution and statistical analysis were used. The percent contribution of each isolate was calculated by using the following formula:

Total no. of CFU of an individual species

X $100 \quad$ Total no. of CFU of all species

Table 2:

\begin{tabular}{|l|l|l|l|}
\hline Location & Soil $\mathbf{~ H H}$ & Temperature & Humidity \\
\hline Ariankuppam & 8.1 & $34^{0} \mathrm{C}$ & $50 \%$ \\
\hline Nonankuppam & 7.4 & $33.5^{0} \mathrm{C}$ & $49 \%$ \\
\hline Veerampattinam & 7.8 & $34{ }^{0} \mathrm{C}$ & $46 \%$ \\
\hline & & & \\
\hline
\end{tabular}

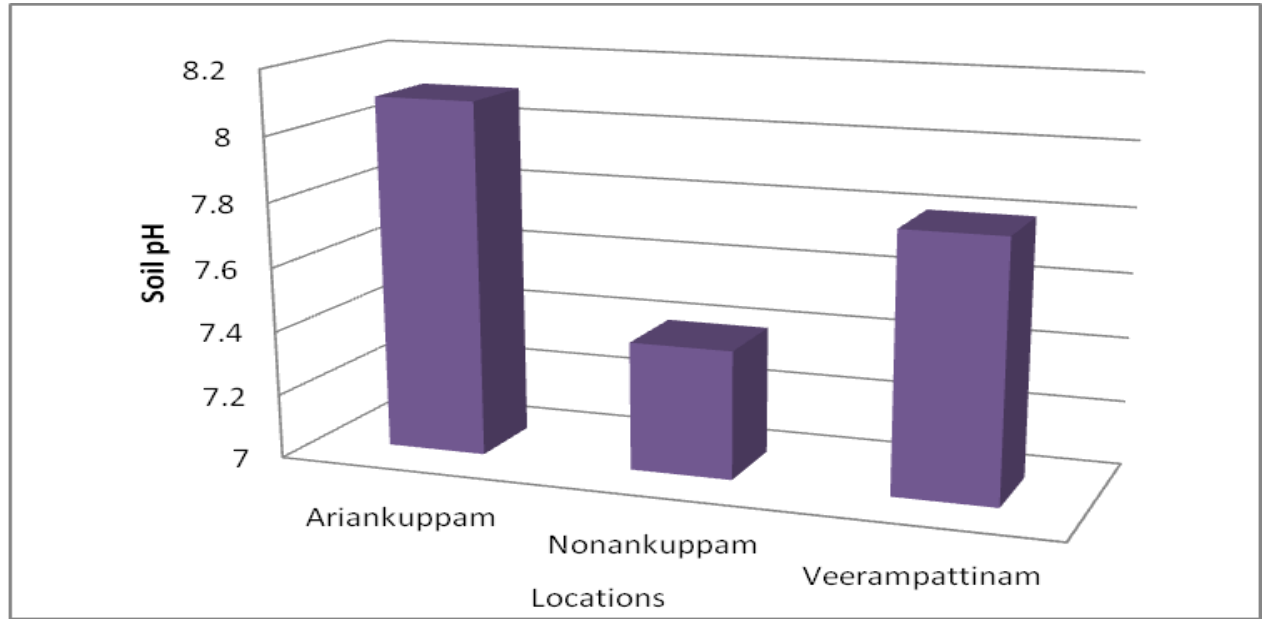


Table 2:

\begin{tabular}{|c|c|c|c|c|c|c|}
\hline S. No. & Fungal species & S 1 & S 2 & S 3 & \% frequency & F. Class \\
\hline \multicolumn{7}{|c|}{ Zygomycotina } \\
\hline 1 & Mucor racemosus & + & + & + & 100 & $\mathrm{C}$ \\
\hline 2 & Rhizopus oryzae & + & + & + & 100 & $\mathrm{C}$ \\
\hline 3 & Rhizopus stolonifer & + & - & + & 0.67 & $\mathrm{~F}$ \\
\hline 4 & Absidia glauca & + & - & - & 0.33 & $\mathrm{R}$ \\
\hline \multicolumn{7}{|c|}{ Basidiomycota } \\
\hline 5 & Torula herbarum & + & + & - & 0.67 & $\mathrm{~F}$ \\
\hline 6 & Pseudotorula & + & - & - & 0.33 & $\mathrm{R}$ \\
\hline \multicolumn{7}{|c|}{ Heterokontophyta } \\
\hline 7 & Pythium sp. & - & + & + & 0.67 & $\mathrm{~F}$ \\
\hline \multicolumn{7}{|c|}{ Ascomycota } \\
\hline 8 & Aspergillus candidus & + & + & + & 100 & $\mathrm{C}$ \\
\hline 9 & Aspergillus flavus & + & + & + & 100 & $\mathrm{C}$ \\
\hline 10 & Aspergillus fumigatus & + & - & + & 0.67 & $\mathrm{~F}$ \\
\hline 11 & Aspergillus nidulans & - & - & + & 0.33 & $\mathrm{R}$ \\
\hline 12 & Aspergillus niger & + & + & + & 100 & $\mathrm{C}$ \\
\hline 13 & Aspergillus sydowi & - & - & + & 0.33 & $\mathrm{R}$ \\
\hline 14 & Aspergillus terreus & + & + & - & 0.67 & $\mathrm{~F}$ \\
\hline 15 & Aspergillus ustus & - & + & - & 0.33 & $\mathrm{R}$ \\
\hline 16 & Botrytis sp. & + & - & - & 0.33 & $\mathrm{R}$ \\
\hline 17 & Curvularia sp. & - & - & + & 0.33 & $\mathrm{R}$ \\
\hline 18 & Fusarium sp. & + & - & - & 0.33 & $\mathrm{R}$ \\
\hline 19 & Penicillium chrysogenum & + & + & - & 0.67 & $\mathrm{~F}$ \\
\hline 20 & Penicillium citrinum & + & - & + & 0.67 & $\mathrm{~F}$ \\
\hline 21 & Phoma leveillei & + & - & - & 0.33 & $\mathrm{R}$ \\
\hline 22 & Trichoderma viride & + & + & - & 0.67 & $\mathrm{~F}$ \\
\hline 23 & Verticillium lecanii & - & - & + & 0.33 & $\mathrm{R}$ \\
\hline 24 & White sterile mycelia & + & + & - & 0.67 & $\mathrm{~F}$ \\
\hline 25 & Grey sterile mycelia & + & - & - & 0.33 & $\mathrm{R}$ \\
\hline
\end{tabular}

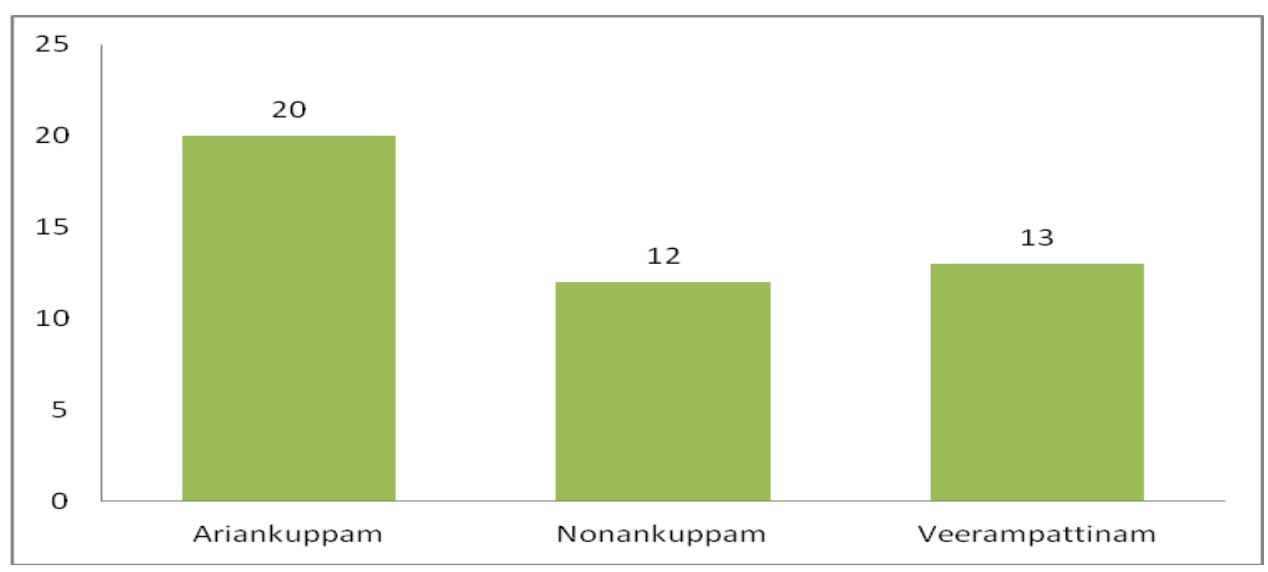


The present study revealed that 45 fungal CFU's were isolated from the three different sites. 20 different species were isolated in the Ariankuppam soil belong to three different genera (S1), 12 species of 4 genera were identified in the Nonankuppam (S2) soil. The S3 veerampattinam soil consist of 13 different fungi of 4 different genera were also isolated. The enumeration showed that there are 5 frequently occurring fungi present in all the three soil samples belong to three different areas. The samples collected were neutral and alkaline supports the major growth of fungus. The S2 and S3 soil samples exhibited the growth of pythium sp. of Heterokontophyta genus.

The fungi include Aspergillus and Penicillium spp., are prevalent in the three samples they are ubiquitous as well as their predominance in coastal soils were early reported by researchers. (Domsch 1980). These results were in accordance with our result which included Absidia spp,Alternaria spp, Aspergillus spp, Paecilomyces spp, Penicillium spp, and Trichoderma spp. Genus Aspergillus mainly Aspergillusflavus was the highest occurrence followed by A. niger, and A. fumigatus. Aspergillus genus has been cited as one of the fungi which are present in the atmosphere and soils of various areas (Kathiresan 2001; Larrondo 1989; Migahed 2003) Aspergillus showed the broadest spectrum range, it represented by five species of Aspergillus flavus, A. versicolor, A. fumigatus, A. niger, and A. terreus. Similar to this result, found that the Aspergillus spp. were the dominant fungi in mangrove ecosystem. Typically, reported that Aspergillus spp. were the most diverse genus isolated from a soil sample from mangrove soils of puducehrry region. The environmental saprophytic fungi were the most common in the coastal soil of Puducherry (Kathiresan 2001). It was worth mention that the total count of the genera or species in the twenty four soil sample did not always follow the number of case of isolation (Migahed 2003, Oliveira et al., 1993, Onions 1986 ).

\section{References}

1. Ainsworth GC and Bisby GR (1995). Dictionary of the fungi. Commonwealth Mycological Institute Kew, Surrey 445. Research in Microbiology 155 587-595.

2. Barnett, H.L. and Hunter, B.B. (1972). Illustrated genera of imperfect fungi. (3rd Ed.) Burgess Publishing Co. Minneapolis, Minnesota. 226 pp.

3. Diana WF (1994). Soil biodiversity: its importance to ecosystem processes. Report of a workshop held at the natural history museum, London, England.

4. Domsch, K. H., Gams, W. and Anderson, T. H. 1980. Compendium of Soil Fungi. Academic Press, Inc. New

5. Ellis, M.B. Dematiaceous Hyphomycetes, Common Wealth Mycological institute Kew, Survey, U.K. 1971.

6. Ellis, M.B. More Dematiaceous Hyphomycetes, Common Wealth Mycological institute Kew, Survey, U.K. 1976.

7. Ellis, M.B. and Ellis, J.P. Microfungi on land plants, Biddles Ltd., Guildford and King's Lynn, Great Britin. 1985.

8. Filion Cassel, D.K., and Wollum, A.G., 1999. Effects of soil sample size and included root and wood on bulk-density in forested soils.Soil Sci. Soc. Am. J. 45, 135138.

9. George, G.W., and Cochran, W.G.1989. Statistical Methods. The Iowa State University Press, Ames,IA.

10. Jackson, M.L., 1973. Soil chemical analysis. Prentice Hall of India Pvt. Ltd., New Delhi.

11. Kathiresan, K., and Bingham, B.L. 2001. Biology of mangrove and mangrove ecosystems. Advances in Marine Biology, 40: 81-251.

12. Larrondo, J. V., and Calvo, M. A. 1989.Fungal density in the sands of the Mediterranean coast beaches. Mycopathologia. 108: 185-193. 
13. Meyer, G. H., Prince, H. E. and Raymer,W. J. 1983. Airborne fungi A resurvey.Ann. Allerg. 51: 26-29.

14. Migahed, F. F. 2003. Distribution of Fungi in the Sandy Soil of Egyptian Beaches. Mycobiology 1(2): 61-67.

15. Molin., and Molin.1997.De ning Soil Quality for a Sustainable Environment. American Society of Agronomy, SSSA Special Publication No. 35,Madison, WI. Pace, J.L. 1999. Analytical approaches to the characterization of samples of microbial communities using patterns of potential C source utilization. Soil Biol. Biochem. 28, 213221.

16. Oliveira, M. T. B. D., Braz, R. F. S. and Ribeiro, M. A. G. 1993. Airborne fungi isolated from Natal, Satate of Rio Grande do Norte-Brasil." Rev. Microbiol. 24: 198-202.

17. Onions, A.H.S.; Allsop, D. and Eggins, H.O.W. Smith's introduction to industrial mycology, London, Edward Arnolod. 1986.

18. Pinto, I. M. A., Cavalcante, M. A. Q. and Passavante, J. Z. O. 1992. Hongos filamentosos aislados desde el suelo y agua en la Playa de Boa Viagem (Recife-Brasil).." Bol. Micrologico. 7: $39-45$.

19. Sarquis, M. I. M., and Oliveira, P. C.1996. Diversity of microfungi in the sandy soil of Ipanema Beach, Rio de Janeiro, Brazil. J. Basic Microbiol. 36: 51-58.

20. Subramanian C.V., Hyphomycetes, Taxonomy and Biology Academic Press. London. 1983.

21. Timonen, R.R., and Rohlf, F.J. 1996. Biometry. Freeman, New York, NY.Upadhyaya, A., Tunlid, A., Baath, E., 1998. Phospholipid fatty acid composition, biomass and activity of microbial communities from two soil types experimentally exposed to different heavy metals. Appl. Environ. Microbiol. 59, 3605-3617.

22. Trevors, F.D. 1998. Analysis of the dynamics of bacterial communities in the rhizosphere of the chrysanthemum via denaturing gradient gel electrophoresis and substrate utilization patterns. Appl. Environ.Microbiol. 64, 49504957.

23. Waksman SA (1927). Principles of soil microbiology. Bailliere Tindall \& Co., London.

24. Warcup,J.H. , 1955. Trans. Br. Mycol. Soc., 38,298-301.

25. Yao,K., D.Hahn, W.Honerlage, F.Schonholzer, and Zeyer, J.2000. In situ detection of spores and vegetative cells of Bacillus megaterium in soil by whole cell hybridization. Syst. Appl.Microbiol. 18, 265273. 